\title{
Revolution in the air: images of winning in the Irish anti- capitalist movement
}

\author{
LAURENCE COX \\ Department of Sociology, National University of Ireland, Maynooth \\ LIZ CURRY \\ Researcher, Dublin City University
}

\begin{abstract}
This article explores strategic conceptions within the alter-globalisation movement in Ireland. Based on action research carried out within the left-libertarian ("Grassroots') wing of the movement, it notes imbalances in participation in a very intensive form of political activity, and asks how activists understand winning. It finds substantial congruence between organisational practice and long-term goals, noting social justice and participatory democracy along with feminist, environmental and anti-war concerns as central. Using Wallerstein's proposed transition strategy for anti-systemic movements, it argues that Irish alter-globalisation activists are realistic about popular support and state power, and concerned to link short-term work around basic needs with the construction of alternative institutions and long-term struggles for a different social order.
\end{abstract}

Key words: social movements, Ireland, alter-globalisation, anti-capitalism, strategy, utopia

\section{Introduction: alter-globalisation and Ireland}

In 2010, the worldwide alter-globalisation movement is fifteen years old, dating from the first Zapatista-sponsored Encuentros, which in turn gave rise to the People's Global Action alliance that shut down the World Trade Organisation in Seattle in 1999 - since which point it has been unable to conclude a single trade round. Irish participants were first involved in the 2000 and 2001 protests in Prague and Genoa respectively, while 2002 saw the police discover that the media and other elites did not accept the licence they believed they had to attack participants of a Reclaim the Streets party in Dublin (Ní Dhorchaigh and Cox 2009). If the movement has had a considerable impact globally (Hilary 2009), while its critique of ecologically destructive capitalism has become mainstream (Bunting 2009), matters are less clear-cut in Ireland, where it was possible to 
use warships and paramilitary violence to break fishermen's opposition to the Shell pipeline in Erris without substantial public outcry, and where government cuts are significantly to the right of the International Monetary Fund's advice that recession still needs to be countered by economic stimulus.

It helps, of course, that even 'serious' media routinely trivialise or criminalise alter-globalisation activity (Browne 2004; Meade 2005). Perhaps more importantly, older social movements (trade unions, community groups, women's organisations etc.) are 'embedded' in state policy and funding processes in ways which make practical dissent an unacceptable risk. Nevertheless, even within these movements radical minorities have argued powerfully against social partnership and for more disruptive strategies as the most effective way forward (Piven 2008) - an approach which is likely to gain favour in the current crisis, as partnership is unilaterally abrogated from above. Elsewhere, the government was forced to militarise Dublin city in order to avoid embarrassment at the 2004 EU summit (Dublin Grassroots Network 2004). Opposition from the left was instrumental in rejecting the neo-liberal Lisbon Treaty (and further undermining the EU's claim to democracy as the vote was rerun to achieve the 'correct' result). Activists have delegitimated the use of Shannon airport by the US military and CIA and have drawn attention to Ireland's role in torture flights, while participation in the February 2003 anti-war protests was of a once-in-adecade scale. Finally, an alliance between local farmers and fishermen, radical ecologists and the broader anarchist, socialist and republican left has been instrumental in stalling the world's largest oil companies, who at time of writing have just announced that the Rossport pipeline - still lacking approval - will not be built until 2011, over a decade after the first planning application. It is by no means certain that it will happen in 2011 either. This variety of experiences gives a sense of the complexity of the Irish 'movement of movements' against neo-liberalism: formal organisational cooperation is rarely long-lived and typically restricted to individual campaigns. It can draw, however, on a long history of anti-capitalist organising and thinking, as well as a substantial history of formal and informal networking processes. (For an overview of the Irish movement, see Cox 2006; for a social movements perspectives on alter-globalisation, see Cox and Nilsen 2007.)

\section{Strategy and alter-globalisation}

Strategic debate is necessarily at a premium in the alter-globalisation movement internationally. 'Anti-systemic movements' (Arrighi et al. 1989) herald and accentuate the crisis of regimes of accumulation; the alter-globalisation movement does this for neo-liberalism in ways comparable to the challenge posed by the movements of the 1960s and 1970s to organised capitalism (Lash and Urry 1987, Wainwright 1994). At a time of movement growth and success (most visibly in Latin America) and regime crisis (most visibly around war in the middle East, the neo-liberal economic project and global warming), the 
question of 'what should we do?' necessarily goes much further than it does at times of 'business as usual'. The movement as such, in fact, is constituted precisely around the recognition that opposition to neo-liberal capitalism can provide a 'master frame' capable of allying a wide range of movements around a perceived 'political opportunity' of going beyond the pursuit of more restricted goals; but this master frame is itself the subject of intense contestation.

Because such crises are exceptional, very few participants can rely on personal experience and routine in the way that (say) NGO policy workers can; theory is an indispensable practical guide to unknown territory. Furthermore, since participants aim beyond the continuation of existing social relationships, issues of utopian imaginary - and of the relationship between ends and means - are necessarily part and parcel of the process of social movement. Since power has become increasingly 'disembedded' from community, workplace and even the nation-state, actors search for tools with which to conceive the world they are in, the world they would like to reach, and the process of getting there. There is of course a good deal of 'noise' in the articulation of such visions, from mainstream academics (Tormey 2004; Stiglitz 2007) to movement-sympathetic journalists (Monbiot 2004) whose primary audience is constructed through university courses or 'serious' news media. There are also movement actors which substantially refuse such articulation, whether because of a prior commitment to 'business as usual' as their only mode of operation or because of inability to articulate a strategy consistent with their vision.

Attempting to find a way around this are 'movement utopians' such as the Parecon school (Albert 2003) and Lebowitz (2006) or the ecologically localist vision of Douthwaite (1996), as well as the substantial refusal of strategic thought by autonomist authors such as Hardt and Negri (2000, 2004), Holloway (2005) and the Turbulence collective (2010). There are also a series of well-articulated strategic visions proceeding from different corners of the movement and representing more or less well-organised actors. We can contrast, as Abramsky (2008) does, the 'Bamako Appeal' of movement intellectuals such as Samir Amin to the 'Sixth Declaration from the Lacandon Jungle' announcing the Zapatista's ongoing 'Other campaign'. We can note strategic interventions from relatively conventional Marxist viewpoints such as Harvey's (2009) transition strategy, ${ }^{1}$ those calling for new kinds of internationalisms (Waterman 2001), those attempting to bring the perspective of indigenous populations centre-stage (Sen 2009) and those celebrating the coexistence and interaction of radically different perspectives as itself part of the goal (de Sousa Santos 2006). A particularly important place in this process is held by the World Social Forum, as the most visible site of networking within the 'movement of movements', and particularly the work of those associated with debates around Forum processes, intent on bringing what has been learnt in organising movements of the poor to organisation at this new level. 


\section{The alter-globalisation movement in Ireland: strategies and visions}

It is one thing to describe the positions of the most organised movements, and their most articulate intellectuals, in terms of strategy and vision. It is another thing altogether to find out what ordinary movement participants think about their own activity - and indeed whether they see themselves as being part of a single movement. This section of the paper sketches a brief institutional overview of the alter-globalisation movement in Ireland and outlines the methodology and findings of a piece of research carried out with participants in the Irish movement around their understandings of their own activities, strategies and goals and how they understood what it would mean to win.

Any movement - or, as here, any alliance of movements - naturally has a strong tendency to conceive of its strategies and goals in ways determined by its participant organisations and networks. Alter-globalisation movements vary globally to a remarkable degree (Polet 2004): where in the majority world (and in particular in Latin America, South Africa and South Asia) the driving force is movements of the poor (small farmers, indigenous populations, shantytown dwellers etc.) supported by some fractions of the urban, educated Left, trade unions and NGOs, in the North the relation tends to be reversed and it is a substantial achievement when - as at times in Italy - successful links are built to community and neighbourhood groups, precarious workers and illegal immigrants. ${ }^{2}$ The Irish movement is shaped by two decades of 'social partnership' tying in the larger part of Irish social movements (unions, community groups, environmentalists, the women's movement, development organisations, anti-racist and health-oriented groups) to seeing 'working within the system' as the only serious way forward. Hence only in movements which have not operated in this way (primarily the peace movement opposed to Ireland's increasing support for US and European military strategy) or where partnership has been seriously contested (trade unionists who reject the EU's neo-liberalism, ecologists opposed to the state's policy of 'development at any cost' and feminists and anti-racists who see the state as part of the problem rather than a tool for 'raising awareness') that the movement has found participants, along with elements of the non-institutional left and poor communities which have been failed by the state. ${ }^{3}$

Drawing on earlier networking processes between social movements and the broader 'movement cultures' of particular localities, the Irish movement has gone through several phases which have been discussed elsewhere (Cox 2006) and is now in changing shape as economic crisis leads the state and employers to unilaterally withdraw from partnership. This will probably lead to a crisis of those social movement organisations which have been structured around it and now face exclusion from decision-making processes and massive cuts in funding both for their organisations and (in the case of trade unions and community 
groups in particular) for those they represent. In these last two cases at least, there are long-standing communications between some sections of the movements and opponents of neo-liberalism and partnership; in other cases perhaps nothing will be learnt, or salvaged, from the collapse of social partnership.

The formal expressions of the Irish movement to date have taken a range of forms, including the short-lived but broad-based Irish Social Forum, a series of SWP-led alliances (Irish Anti-War Movement, Another Europe Is Possible, People Before Profit, etc.) and most recently the Bloom! initiative of majority world solidarity organisations. Unusually in a comparative perspective, the greatest organisational continuity has been provided on the left-libertarian wing of the spectrum by the Grassroots Gathering networking events from 2001-08 (Cox 2007), which formed the starting point for direct action against the US military use of Shannon airport (as 'Grassroots Network Against War'), opposition to the 2003 World Economic Forum visit - and contributing to its cancellation, the May Day 2004 protests against the 2004 EU summit (as 'Dublin Grassroots Network'), and more recently in the development of the Seomra Spraoi social centre in Dublin and allied projects elsewhere. ${ }^{4}$

The Grassroots Gatherings were based on the Grassroots Principles, demanding the abolition rather than reform of bodies such as the World Bank and World Trade Organisation as part of a broader challenge to power and inequality, stressing self-controlled workplaces and communities along with environmental and social sustainability. The principles emphasise bottom-up organising strategies and reject top-down and state-centred approaches. Gatherings have been typically twice-yearly meetings of activists involved in different movements and campaigns, focused not on decision-making but on plenary discussions and workshops aimed at sharing skills and reflecting on strategies.

\section{Methodology}

The Gatherings were chosen as the site for this research for a range of reasons. Firstly, because of the organisational continuity already mentioned, and hence the greater period of time in which these questions of strategy and vision for the alter-globalisation movement have been discussed in this milieu. Secondly, because as a network a wide range of movements and campaigns have been consistently present within it, from the Catholic Workers and Shell to Sea via trade unionists and community activists to opponents of the M3 motorway at Tara and radical feminists: it provides an effective location to contact people involved in most of the constituent parts of Irish alter-globalisation. Thirdly, and in some ways most importantly, libertarian perspectives are less likely to find formal, commercial published form.

Most strategies and visions articulated in northern, English-speaking countries for the movement are those coming from critical academics or backed by left parties - 'verticals', as the jargon has it, rather than 'horizontals' - and there is thus more to be learnt by exploring those ends of the spectrum which do not 
have much institutionalised voice, and which tend to less articulated modes of theorising. Research often also bundles activists together with little discussion either of the impact of their goals (revolutionary vs reformist) or their methods and organisational styles (horizontal vs reformist), as though 'activism' was a unified whole, or those with most access to publication were automatically representative of the whole movement.

This research, designed and carried out by Liz Curry with assistance from Laurence Cox, constituted participant action research, a long-standing mode of generating 'movement-relevant research' (Bevington and Dixon 2005). Both authors are long-standing participants in the Grassroots Gatherings, enabling us both to formulate questions effectively and to elicit serious responses. The purpose of the research was to encourage participants to think further about their own goals and strategies, a process inherent in the Gatherings and particularly in the June 2008 Gathering where the data for this research were collected. This Gathering was dedicated to the theme of social movements, and had as one of its three themes 'Learning about grassroots movements'.

A workshop within this theme, on the topic 'What is winning?' formed part of this research, feeding directly back into the movement's own discussion processes. Open-ended questionnaires were also distributed and collected at this Gathering, ${ }^{5}$ feeding in more indirectly to the debates on movement strategy (the other two themes were 'Thinking about grassroots movements' and 'Radical civil society and the state'), while a number of qualitative interviews were carried out separately with movement participants. Finally, the findings of this research were circulated to activists via Indymedia (www.indymedia. ie/article/90741) and otherwise. In terms of data, initial research to establish the spectrum of current thinking among long-standing activists included 7 qualitative interviews with experienced figures across a range of alter-globalisation movement organisations, inside and outside the Grassroots spectrum. There were 12 participants in the focus group ( 9 men and 3 women), with an age range between the early $20 \mathrm{~s}$ and the late $40 \mathrm{~s}$. Their activist background included climate change activism, anti-fascism, trauma support, social centres and anarchism. Participants split into two groups for discussions, followed by a group discussion. A further 29 participants at the Gathering (of approximately 100 attendees) returned questionnaires, as well as one online response. Of these 30 responses, there were 22 men and 8 women; the age range was between 18 and 52 , with an average age of 29.5. This research - in a group which is in many ways self-selected - did not and could not aim for statistical significance, and the use of open-ended questionnaires underlines this. Its strength lay rather in the thoughtful responses of participants to questions which were in any case the subject of significant internal discussion, and our data below - whether raw numbers, quotations or broader syntheses - reflects this fact of a pre-constituted and interactive group context. 


\section{Movement participation}

Some comments are, however, in order on participants' general characteristics, and specifically to explore and explain class, gender and ethnic imbalances, a theme highlighted by participants themselves, most notably in relation to gender. The male:female ratio in the focus group and questionnaires stood at about 3:1, reflecting typical attendance patterns at the more explicitly political Grassroots meetings, and indeed in most Irish social movements other than the women's movement and community organising. The class situation was even more unusual: of 30 questionnaire respondents, only 4 had not attended third-level, while 4 were in third-level and 22 had completed at least an undergraduate degree, if not a postgraduate one. Consistent with this, educational employment was particularly prominent and only 3 respondents had manual working-class occupations, though many were white-collar working-class. ${ }^{6}$ In terms of nationality, the proportion of Irish nationals (22/30) was less than that of the population as a whole (just over 90 per cent), with 4 stating 'Irish and another nationality' and 4 from other west European contexts. However, among the 'non-nationals' there were none from outside the 'developed' world. The sharpest absolute distinction was one of age, with no participants under 18 or over $52 .^{7}$

The question of age (which impacts on educational status given rising college attendance over time) is easiest to explain: as for studies on post-1968 'new social movements' and the findings of political sociology generally, political socialisation is a generational phenomenon, dependent on the creation of activist socialisation structures which continue to affect subsequent generations but rarely reach back to older ones. Consistent with this, we can note a broadening of age already by comparison with the data gathered in 2001 by Bramble and Minns (2005), where 50 per cent of participants were still students.

Leaving age aside, how can we analyse these various disparities? Arguably there are both internal and external issues involved (Cox 2007). Internally, the authors have long argued that the Grassroots Gatherings need to work harder to 'speak to' different social groups, in terms not only of language but also of themes and interests and ways of working. Externally, political participation is not as readily available as choosing a television station: social inequality creates barriers to political participation at every level, barriers which are raised when the participation in question involves high-risk, time-consuming activism and is geared to strategic political thinking. Participants highlighted these imbalances as a key issue of concern in relation to their own groups, and society as a whole. As one respondent noted of the question:

This is circular - the problem with this society is that most people can't be fully participating in 'winning' their world. The reasons are capitalism, particularly racial and labour divisions. There is inevitable unevenness in those who can become active in radical politics and avoidable divergences in different kinds of radical politics. 
Another way of thinking this is in terms of the limited reach of alliance-building processes: if the Grassroots Gatherings were successful at building links between elements of the radical left and ecologists (for example), they were less so at making alliances with the women's movement, working-class organisations or migrant rights groups (though international solidarity is well represented). In terms of migrants' rights, the recent Bloom! network of immigrant organisations around global justice shows what can be achieved in this space. In terms of working-class organisations (other than the union efforts represented by the Gatherings' radical left components), repeated efforts to make alliances with community groups have been largely unsuccessful. In terms of the women's movement, it may be helpful to think of groups like RAG and Choice Ireland as representing an overlap between the anarcha-feminist wing of anti-capitalism and the radical, direct action wing of Irish feminism. At this political level, then, much remains to be done.

\section{Levels of political activity}

Participants were, as expected, highly involved politically. Thirty respondents were involved in 29 different groups and networks (since a third of respondents named multiple groups, there was substantial overlap of membership). ${ }^{8}$ Groups mentioned included anarchist, feminist, environmental, heritage/resource protection, anti-homelessness, marijuana legalisation, community gardening and social centre groups along with 3 NGOs, 2 political parties and 2 religious networks. Most participants categorised their groups as containing multiple elements or issues; the most widely-shared categories were anarchist (just over 50 per cent) and anti-capitalist (just under 50 per cent), followed by environmental (12 mentions), community (7), human rights (6), single-issue (5) and feminist (4).

Of groups mentioned (bearing in mind multiple memberships), 23 per cent were in groups of 10 regular participants or fewer, 40 per cent in groups of 10 to 30 regular participants, 27 per cent in groups of 30 to 70 , and a surprisingly large 18 per cent in groups of 100 or more (including national and international networks). Bearing in mind the actual numbers of people at most group (committee, strategy etc.) as opposed to public, meetings in almost any political context, this reflects a strong participatory practice, expected for this libertarian milieu, as well as relatively lively social movements. Thus in discussing the strategies and goals of these alter-globalisation activists we need to bear in mind, firstly, that they are social movement activists, and hence relatively self-selected within an unequal society. While research into different wings of the alter-globalisation movement (e.g. radical trade unions or community activism) would change the demographic data, they would hardly change this picture of high levels of multiple organisational membership, involvement in relatively intense social movement organising (large groups of regular participants), and substantial periods of 'apprenticeship' (albeit this might be less mediated through MAs in 
equality studies and more through, for example, trade union, political party or community educational structures).

\section{How do alter-globalisation activists see winning?}

Identities and goals

As della Porta et al. 2006 found, most participants do indeed perceive themselves as part of a broader, and international, movement, in line with the conceptualisation of movement used above. (Only one participant dissented.) However, there was no hegemonic identification of what this movement was: the only categories used more than once were 'anti-capitalist' and 'environmental', with 'global justice', 'movement of movements', 'anti-globalization movement' used once each. More commonly, people identified with a shared movement culture ("network of empathetic activists' being a particularly good example) or with a specific theme or issue (“women's movement', 'anarchist movement'). Thus there is widespread agreement among participants that they are part of something larger, but not what that something is; its boundaries are, of course, part of what is fought over in movement strategising processes (Barker and Cox 2001). This finding probably also reflects the relatively low level of formal organising. Contra Castells (2004), whose arguments lead us to expect networks as the main unit of social movements, the main unit in Ireland is the informal group: affiliations named by participants included 21 informal groups, 7 networks and only 3 organisations with formal membership - two political parties and one party-like anarchist organisation.

Obviously enough, given that international debate processes are mediated through formal organisations and networks, participants in informal groups without deep organisational links to other groups abroad find it easier to have a general sense of shared identity rather than the kind of defined position which may reflect, for example, a network's position on how the World Social Forum should define itself.' This shared identity is anti-systemic rather than 'singleissue': of the many varied conceptualisations of the wider movement, the most common were variants on anti-capitalism, anarchism, environmental and social justice, reflecting the historical origins of the Grassroots Gatherings in an alliance between class-oriented anarchists and radical ecologists. ${ }^{10}$ Participants are still grappling towards an effective way of identifying the movement they are conscious of being part of, while the inherently international character of this movement identification combines with loose organisational structures in Ireland to make this debate less than urgent. There is, nevertheless, a shared perception of being part of a wider movement which is broadly anti-capitalist and environmental, and based on radical participatory democracy and sustainability.

Participants' goals reflected long-standing trends in social movement politics globally. In keeping with a general radical left (post-Stalinist, post-Social Democratic) trend, means and ends are seen as closely linked, and bottom-up 
change and democratic and participative organisation are seen as essential parts of the goal as well as of the process (Fominaya 2010). Reflecting the alter-globalisation movement's experience, the key conditions mentioned for achieving movement goals were process, solidarity, network building and personal development - this last also a goal as well as a means.

Following two decades of 'red-green' dialogue (Epstein 1991; Red-Green Study Group 1995, etc.), social justice and environmental sustainability are central parts of the goal, and associated with feminist and anti-war themes. These themes were widely shared, and linked, both by those currently involved in 'single-issue' groups and those involved in groups based on specific political strategies. This last distinction, separating groups rather than individuals (who were often involved in both kinds), is between short-term and long-term politics: the majority of those who saw their goals as achievable within twenty years were involved in single-issue campaigns around a concrete goal. There was also broad optimism among those in groups with long-term anti-systemic goals; only two respondents were not optimistic about achieving their goals, of whom one was not in a group and the other, in a development NGO, saw global poverty and inequality as increasing, with no good prospect for change. This optimism - despite a global decrease in collective action since the early 2000s and in Ireland since 2005 - reflected both a historical viewpoint and a long-term strategy which included organisational development as part of the process. One respondent commented:

We are doing far better than in 1998. We are probably in the end phase of neolib institutions as the 60s and 70s were the end-phase of Keynesian/organised capitalism.

Another wrote:

In terms of a just bottom-up global society, global movements and the poor are stronger now than for many years. It's a long, global process.

At the broadest level, participants overwhelmingly felt that what the wider movement needs to do to win is to build unity and solidarity, to connect and organize, to use and create alternative media and structures, and to believe winning is possible:

Ni neart go cur le chéile.

Another still echoed Wallerstein (2002):

The essence of radical politics is transforming general alignment with the best of people's needs, aspirations, desires to action in line with that, successfully offering new directions in crisis of neo-lib as against business as usual and alternative to new world order from above, developing dual-power institutions to point where old structures start to lose solid grip, defeating the inevitable backlash (war, criminalisation etc.) 


\section{Structure and agency}

How did this broader picture relate to participants' specific conceptions of structure and agency? Their perspectives were overwhelmingly anti-systemic: about half of respondents described their group as being either anarchist or anticapitalist, while about a third of the twenty-five main goals listed explicitly discussed the abolition of capitalism and its replacement with an alternative social, political and economic system, with only seven goals being 'singleissue'. This appears at first sight utterly marginal, if we believe that the Irish media and political parties are an accurate reflection of popular feelings and beliefs. However, a recent BBC poll in twenty-seven countries (Hyland 2009) found that three in five respondents were opposed to free market capitalism and almost one quarter believed that capitalism as a whole should be replaced by a different system, suggesting that these views draw on wider popular perceptions which are excluded from institutional politics. Those perceptions are also evident in how respondents identified the external obstacles to their groups' goals: 16 named capitalism, 14 corporate power, 13 state power and 11 international financial institutions. This was followed by more conventional analyses: commercial media (also 11), public apathy and lack of awareness of issues (10 respondents each).

The popular identification of the system as capitalist, rooted in 150 years of socialist and anarchist organising, seems borne out by the fact that neoliberalism was far less 'popular' as an obstacle (9 mentions), while capitalism was also chosen as the main obstacle by those who did not describe their goals as explicitly anti-capitalist, again suggesting that participation in single-issue groups is typically linked to a broader analysis of the problem and strategy for change. While the literature has typically viewed opposition to neo-liberalism as the 'master frame' uniting the alter-globalisation movement, here we see a more explicit systemic critique of capitalism by anti-systemic groups, or as one respondent wrote 'large scale, structural change in the political economy and social practices'. Thus more emphasis on the role of social structure and systemic critique in social movement analysis - more discussion of the 'big opponent' (system) rather than the 'little opponent' (policing, media, mainstream political parties) - may be needed to analyse explicitly anti-systemic movements. In particular, the American tradition of analysing how formal movement organisations mobilise resources for specific campaigns, frame their issues within the media and exploit 'political opportunity structures' may hide a deeper assumption on the part of many researchers that current social arrangements are in essence untouchable. This is very far away from the dominant position within the alterglobalisation movement, in Ireland and internationally, that global institutions are fundamentally flawed and therefore should be disrupted rather than engaged with - a position that runs from the insurrectionary politics of the Zapatista Encuentros via the direct action of the Cochabamba water wars or farmers who 
destroy GM crops, to the organisers of counter-summits and social forums (created, of course, in opposition to the World Economic Forum).

If anything, the participants, particularly those affected most by radical ecology, seem to have all-encompassing notions of ultimate goals, including identifications of winning as 'ultimate, evolving diversity', 'recognition of control of self', 'self-sufficiency, but also inter-dependency', 'stewardship - other species, the environment', and so on. We should also mention here the emphasis placed by several respondents on the building of alternative parallel structures: anti-systemic movements do not and cannot resign themselves to playing within the institutional rules of the game, and for academics to present them as doing so is a form of ethnocentrism, projecting our own interest in the detailed analysis of institutions-as-they-are onto movements which do not accept the need for, nor the given character, of those institutions. This identification of obstacles also highlights the fact that respondents - speaking from experience - are not sanguine about the practical implications of confronting massive systems. When asked about internal obstacles to achieving their goals, the main external issues mentioned highlighted power relations: 'People's experience of their own defeats (personal, local and large-scale)' and '25+ years of working class defeat'. This is also underlined by many respondents rejecting the perception that capitalism as such is in crisis, or arguing that capitalism can withstand crisis and subsume opposing forces and ideas.

Similarly, the main internal obstacle identified was fear, associated with 'people's sense of powerlessness and the deep-seated social hegemony of capitalism' and 'believing too strongly in the elite's own self-image of real, active popular support across society'. This stress on the effect of capitalist hegemony on movements - in activists' lack of self-confidence and in the actual power of the system - came across strongly in interviews, focus group discussions and questionnaire responses: it is a central practical concern of alter-globalisation activists in Ireland, including those who do not frame it in the language of the left or social science, such as the respondent who highlighted 'the need to evolve away from limited beliefs' as an antidote. What our respondents' perspectives suggest is rather that opposition to structure (and not simply to institutions or outcomes) as the target of their actions is a central part of the movement's self-organisation, and that this needs to be taken seriously in analysing the movement's activity. Participants in the alter-globalisation movement are serious about fighting capitalism, clear about the long-term nature of this struggle, and systematic in their attempt to connect short-term campaigns and local issues with this broader conflict. They may or may not win, but it makes little sense to analyse them as though they were not making a serious effort to do so. 


\section{Visions and strategies}

Irish alter-globalisation activists are not keen on writing the 'cookbooks of the future'; two-thirds of respondents framed their critiques of capitalism in terms of social equality and 'horizontal organising' - equality as a political practice. Goals and visions were similarly described in terms of underlying values rather than as detailed alternative models. Only two respondents had a concrete alternative structure to propose, in both cases based on anarchist principles:

Anarchist communism - the abolition of wage labour and the state, the communization of the means of production and world organisation through a system of federated freely associated councils/communes.

and

Libertarian communism, a society organised on the principle that people affected by a decision get to make the decision, people co-operate and society isn't divided between order-takers and order-givers, direct democracy and true equality.

As the earlier discussion has shown, other respondents did not refuse concepts of social justice or environmental equality, but their primary interest lay in the practice of an alternative way of being, with each other, in struggle, and the attempt to generalise this experience and struggle. This favouring of lifeworld-immanent potential over transcendent goals is also clear when we come to explore the political contexts of respondents' activism. Just over half of respondents were in groups with no specific political basis (meaning not that they themselves lack a broader perspective, but that they work with those who do not). Most of the remainder described the basis of their groups as being various forms of anarchism, followed by anti-capitalism and in one case anti-neo-liberalism.

This general tendency was reflected in the forms of organisation, unsurprisingly since the Grassroots Gatherings were conceived as a coming-together of the horizontally-organised wing of the alter-globalisation movement. The only exceptions to this were three NGOs, one religious network and one political party. Asked to identify the organisational character of their group, 16 respondents described their groups as anarchist in form, with anti-capitalist and environmental having 14 and 12 mentions respectively. Politically, themes such as feminism, environmentalism and social justice were widely shared irrespective of how groups' ideology was described. The anarchist form was more widespread than anarchism as the political basis for groups (10 respondents), perhaps because anarchism (with a small a) is associated with horizontal methods of organising, equal participation and a 'DIY' attitude. One respondent noted that anarchist methods are de facto organisational tools for grassroots movements, including groups which do not describe themselves as anarchist and may not even be anti-systemic, but have taken on ways of organising, decision-making and facilitation associated with the anarchist tradition. (Gordon 2008 and Maeckelbergh 2009 have both argued that this has been one of the major impacts of the alterglobalisation movement on social movements globally.) 
In Ireland, anarchist or left libertarian organising methods have been particularly visible in pro-choice activism, opposition to water and 'bin taxes', in opposition to neo-liberal institutions (World Economic Forum 2003, EU 2004, Bush visit 2005, World Bank 2007, Lisbon Treaty referenda 2008/09), in direct action at Shannon and in opposition to the Shell pipeline at Erris, Mayo. A key factor in this is the platformist anarchist Workers' Solidarity Movement, which has gained influence among other activists both through the involvement of the organisation and individual members in a wide range of movements and through its perceived lack of ambition to control campaigns and movements in which it is involved - a key concern for many members when facing parties or party-like groups. Lacking, as Graeber (2004) has noted, the cultural capital of Marxist intellectual traditions, and often less personally familiar to scholars than state-centred traditions such as feminism or social democracy, anarchism has been under-discussed in much of the literature on the alter-globalisation movement. Its influence - like that of other traditions - varies significantly between different countries and regions. Cox (1999) argued that anarchism, along with other bottom-up organising strategies, could be expected to do well in the period of disorganised capitalism, as against the dominant role of social democracy and Stalinism in the period of organised capitalism and the centrality of states as economic actors.

\section{Conclusion: Wallerstein and Grassroots activists}

How can we assess the strategic visions of Grassroots activists? Of course, as authors such as Harvey (2009) have observed, the nature of crisis is precisely that there is no single, inevitable and automatic outcome; and the purpose of strategy is precisely to provide guidance in this situation. Nevertheless, the fact that crisis actors are necessarily aiming to turn potentiality into reality does not mean that we cannot assess the question of the workability of their strategies for doing so. Here, we want to use Wallerstein's (2002) proposal to structure such an assessment. Wallerstein proposes a transition strategy for anti-systemic groups based around four principles: constant, open debate over goals; short-term defensive action based around needs; interim goals, including ever-widening de-commodification; and developing the substantive meaning of long-term goals. Do Irish anti-capitalists think in this way? In 2008, participants were divided on whether or not capitalism (or neo-liberalism) was in crisis. However, most did not view crisis as inevitable or as a necessary prerequisite for movement success; two of our interviewees reminded us that the the 1930s led to fascism rather than left victories. In general, participants felt that the important task was to construct alternatives regardless of crisis.

If in this respect their perspective differs from classic Marxism, at a broader level there are similarities: over half of our respondents cited what we might call the objective or rational necessity for alternatives as a reason for being confident 
in success. A third of participants felt that their ways of organising were another factor likely to have positive results. Most rated national support for their main goals at 10 per cent or less, though they accurately perceived global support as being higher, particularly in the global South, and as varying over time. They are in this sense rational, but not in the immediate: they see a real potential, a real need and believe that their practice can effectively mediate between these. In terms of short-term defensive action, material needs were unsurprisingly a major focus of discussion. Questionnaire respondents frequently listed involvement in community activism as part of both their short-term goals and their longer-term strategy, while focus group discussions mentioned the importance of building alternatives in areas such as healthcare and education, where the state is unwilling to respond to felt needs. The necessity of building community and combating isolation - responding to psychological as well as material needs - was strongly emphasised.

By contrast, the much-discussed crisis of representation was not mentioned at all; left-libertarian activists in particular take this as a given, and are less nostalgic for a more representative past or ideal public sphere. Several respondents did mention the importance of affecting the political process, including through conventional means such as lobbying and putting pressure on politicians and state institutions; this was unsurprisingly common for single-issue campaigns such as resource and heritage protection. However, by comparison with traditional reformist approaches, this deployment of conventional means goes hand-in-hand with the use of non-violent direct action as a means of disrupting 'business as usual' and drawing public attention to issues. Thus contra Wallerstein (but consistent with his emphasis on the declining role of the state), participants see little benefit from electoral participation; they see the state as one arena among others. The construction of alternatives throws up other questions around how to interact with state and other powerful institutions, although in the context of recession well-known problems with accepting funding (INCITE! 2007) are unlikely to be at the forefront of debate. Recently the movement has seen more collaboration with NGOs, and more willingness to work strategically with the media, but within a radical, horizontal and anti-neoliberal framework which sets sharp limits to both kinds of engagement.

Achievable concrete goals mentioned by participants - between the short and medium term - included an emphasis on anti-racism, immigrant and prisoner support, and policing the police, including a focus on racist attacks and deaths in police custody. Constructively, spreading alternative political viewpoints and building alternative structures around childcare, healthcare and education were further goals. Here the medium is also the message, in that a concrete goal such as setting up a project or getting involved in a campaign is simultaneously an experiment in decision-making and horizontal organisation, a creation of activist communities and infrastructure, and an attempt to get more people involved. In bottom-up perspectives, speaking political ideas, building networks 
and mobilising people are not separate tasks from the winning of campaigns and the creation of successful institutions. Developing alternative institutions is of course a key part of de-commodification; Wallerstein's third point is that this should be a central part of developing effective middle-range goals. Decommodifying goods, services, relationships and spaces has been a key theme of left-libertarian groups in the North since the 1960s, including squats, social centres, info shops, Indymedia, Food Not Bombs, Reclaim the Streets, Buy Nothing Day and so on. The focus group placed particular emphasis on this in relation to consumerism and social relations. The construction of alternative institutions - Klein's 'reclaiming the commons' (2000) - is viewed by activists both as a way of undermining the logic of capitalism and as a way of demonstrating alternatives, particularly alternative ways of organising (see Böhm et al. 2010 for more reflections on this). One interviewee noted that a major challenge facing his organisation is the dependency culture, and that new participants have to change their expectation both of what organisations are and of what their own roles are.

This research was carried out in a period of transition within the movement, with a shift away both from set-piece confrontation and from emphasising identity, towards a broadening of participation and consequently of language in the context of institution-building such as community gardening, refugee support, providing language classes, alternative educational projects and so on. The Seomra Spraoi social centre in Dublin in particular has been a centre of such experimentation, and has taken a strategic choice to highlight openness to different social groups at the expense of aggressive assertions of identity (see Rutkowska 2010). Finally, Wallerstein's first and fourth points - open debate and the articulation of long-term goals - are in practice interrelated. Alterglobalisation activists tend to avoid detailed discussion of hoped-for outcomes in favour of broad arguments for participatory democracy and equality. A strong left-libertarian position naturally expects a future world to mirror the diversity and self-organisation of current movements, perhaps sharing underlying principles but operating in very different ways in different circumstances. By contrast, a strong centralising position is geared towards producing a single 'way of doing things' which can then be proposed, modified and argued for as a unified model.

Nevertheless, participants in the focus group had quite a bit to say about general principles, when asked what winning would look like if no current limits existed. Answers were varied, but linked themes included - beyond the shared focus on social justice and self-organisation mentioned previously - environmental sustainability, living simply and promoting the concept of enough and 'anti-newness', combating consumerism and dependence, combating disempowerment and a 'service provision' culture by promoting personal responsibility and self-organisation, and combating alienation and isolation by building a sense of community. Organisational aspects mentioned included 
social organisation at community level, an end to wage labour (characterised as working when and if you want to), and a cash-free economy.

Some participants, however, refused the question, noting that individual societies could not exist unilaterally outside of capitalist power relations and the global system - in effect arguing that change had to be global and was thus too broad to discuss. This was the only area where discussion of crisis became particularly relevant to participants, with one interviewee arguing that the development of alternative institutions was unlikely to have developed far enough to prevent an authoritarian outcome to crisis, and another noting that a breakdown of global capitalism would mobilise actors which are currently not active, so that the outcome would be impossible to predict. In this largest-scale strategic sense, these activists - aware of and loosely connected to other movements elsewhere but not in direct contact with them - refused the fantasy of imagined control in favour of a more realistic sense of being one actor among others, grounded in underlying realities and moving in the right direction, but unlikely to sweep all before them.

In conclusion, we can say that the Irish alter-globalisation movement has a highly theorised critique of capitalism and a broadly shared worldview combined with high levels of adaptability and commitment, a realistic sense of the difference between short, medium and long-term goals and of the power of their opponents. They share a radical left political basis and strategic perspective which means that involvement in single-issue campaigns does not become a cul-de-sac as often in movement history. The challenges noted by participants include a lack of resources (including numbers), a need for greater diversity of participants and more effective organisational structures, and a lack (in 2008) of political opportunities.

Participants are clearly 'reflective practitioners' and concerned to refine their practice in areas such as democratic organising, diversity, external outreach, involvement with community campaigns and attempts to build workplace links. There is also an ongoing attempt to formulate lived alternatives and construct institutions based on values of direct democracy and equal participation, and a continued awareness of the international context, particularly the global South. Activists are optimist, feeling that they are capable of reaching their short-term goals and are developing the movement capacity needed to make broader gains. In other words, they are doing all the right things; and (in 2010) they are reorienting themselves to tackle the changed context of recession, which is certainly likely to undermine the power of partnership while releasing large numbers of skilled people capable of participating in time-consuming voluntary activity. Whether this is enough for success in the long-term is another question, but as activists note and their own theories imply, this is not simply up to them. Certainly, by comparison with the proliferation of attempts to revive social partnership or sell radical policies to Fianna Fáil, their activities have a rationality, 
awareness of context and strategic approach that much critical sociology could learn from.

\section{Notes}

1 See the forthcoming debate in Interface 2(1).

2 Della Porta (2007: 233) notes a further distinction between constellations of global justice movements across Europe: countries where global justice issues are linked to neoliberalism at home and disruptive protest, and those where NGOs, lobbying and media campaigns around issues in the South exclude radicalism and struggles at home. Ireland clearly falls into the former camp.

3 For perspectives on these movements more widely, see e.g. Connolly 2003; Powell and Geoghegan 2004; Leonard 2008; Connolly and Hourigan 2006; Allen 2007; and Kirby and O'Broin 2009.

4 A number of participants have carried out research in this area, including Lee 2003; Moffat 2004; Cox 2007 and Davis 2007. Barry Finnegan has also carried out research on the Irish Social Forum, but this proved unavailable.

5 These questionnaires had been piloted in advance and changes made according to respondents' comments. The 33 questions were mostly open-ended, with participants being encouraged to add comments on other issues they felt were relevant and to comment on the questionnaire.

6 By contrast, in the 2006 census only 29.1 per cent of the population had completed third-level education.

7 In 2006 about 47 per cent of the population fell into the 15-44 age bracket.

8 The actual figures for multiple involvement are higher, since this figure represents those who answered the questionnaire in relation to all their groups rather than one only.

9 Formal transnational links from, for example, the $2005 \mathrm{G} 8$ protests had loosened by 2008, but participants were influenced more loosely by movement struggles abroad, particularly in the global South. Gathering participants also have a relatively high level of physical mobility, and many have been involved in social movements in other countries, in Europe and globally.

10 This contrasts with Starr's (2000) analysis of the movement drawing on Englishlanguage websites, which identified a substantial disconnect between environmental and anti-capitalist orientations, perhaps reflecting US political culture.

\section{References}

Abramsky, Kolya 2008. The Bamako Appeal and the Zapatista 6th Declaration. New Delhi: CACIM.

Albert, Michael 2003. Parecon. London: Verso.

Allen, Kieran 2007. The Corporate Takeover of Ireland. Dublin: Irish Academic Press.

Arrighi, Giovanni, Terence Hopkins and Immanuel Wallerstein (1989). Anti-systemic Movements. London: Verso.

Barker, Colin and Laurence Cox 2001. 'What have the Romans ever done for us?', in Colin Barker and Mike Tyldesley (eds), Eighth International Conference on Alternative Futures and Popular Protest: A Selection of Papers from the Conference. Manchester: Manchester University Press.

Bevington, Douglas and Chris Dixon 2005. 'Movement-relevant theory', Social Movement Studies 4(3): 185-208. 
Böhm, Steffen, Ana Dinerstein and André Spicer 2010. '(Im)possibilities of autonomy', Social Movement Studies 9(1): 17-32.

Bramble, Tom and John Minns 2005. 'Whose streets? Our streets!', Social Movement Studies 4(2): 105-21.

Browne, Harry 2004. 'Consenting to capital in the Irish media', Irish Journal of Sociology 13: $129-41$.

Bunting, Madeleine 2009. 'Protesters in Seattle warned us what was coming, but we didn't listen', Guardian, 14 December, p. 25.

Castells, Manuel 2004. The Power of Identity vol. 2. Oxford: Blackwell. 2nd edition.

Connolly, Linda 2003. The Irish Women's Movement. London: Macmillan.

Connolly, Linda and Niamh Hourigan (2006). Social Movements and Ireland. Manchester: Manchester University Press.

Cox, Laurence 1999. 'Structure, routine and transformation', in Colin Barker and Mike Tyldesley (eds), Fifth International Conference on Alternative Futures and Popular Protest. Manchester: Manchester University Press.

Cox, Laurence 2006. 'News from nowhere', pp. 210-29 in Linda Connolly and Niamh Hourigan (eds), Social Movements and Ireland. Manchester: Manchester University Press.

Cox, Laurence 2007. 'The Grassroots Gatherings', Red and Black Revolution 12 (April): $17-21$.

Cox, Laurence and Alf Nilsen 2007. 'Social movements research and the movement of movements', Sociological Compass 1(2): 424-42.

Curry, Liz 2008. 'Goals and Strategies of the Left Libertarian Movement in Ireland: What is Winning?', unpublished MA thesis in International Relations, Dublin City University.

Davis, Donagh 2007. 'Gypsies, Nomads, Pirates and Indians', unpublished MA thesis, Department of Sociology, National University of Ireland, Maynooth.

della Porta, Donatella et al. 2006. Globalisation from Below. Minneapolis: University of Minnesota Press.

della Porta, Donatella (ed.) 2007. The Global Justice Movement. Boulder, CO: Paradigm.

de Sousa Santos, Boaventura 2006. The Rise of the Global Left. London: Zed.

Douthwaite, Richard 1996. Short Circuit. Totnes: Resurgence.

Dublin Grassroots Network 2004. 'Fortress Dublin?', www.ainfos.ca/04/may/ ainfos00175.html.

Epstein, Barbara 1991. Political Protest and Cultural Revolution. Berkeley, CA: University of California Press.

Fominaya, Cristina Flesher 2010. 'Creating cohesion from diversity', Social Inquiry (forthcoming).

Gordon, Uri 2008. Anarchy Alive! London: Pluto.

Graeber, David 2004. Fragments of an Anarchist Anthropology. Chicago: Prickly Paradigm.

Gramsci, Antonio 1991. Il materialismo storico e la filosofia di Benedetto Croce. Roma: Riuniti.

Hardt, Michael and Toni Negri 2000. Empire. Boston, MA: Harvard University Press.

Hardt, Michael and Toni Negri 2004. Multitude. Harmondsworth: Penguin.

Harvey, David 2009. 'Organizing for the post-capitalist transition', Posted to DEBATE list, 14 December.

Hilary, John 2009. 'Anti-capitalism', Red Pepper Dec. 2009/Jan. 2010: 14-15.

Holloway, John 2005. Change the World Without Taking Power. London: Zed. 2nd edition. 
Hyland, Julie 2009. 'BBC poll shows widespread disaffection with capitalism', www. wsws.org/articles/2009/nov2009/bbcc-n12.shtml.

INCITE! Women of Color Against Violence 2007. The Revolution will not be Funded. Cambridge: South End.

Kirby, Peadar and Deiric O’Broin 2009. Power, Dissent and Democracy. Dublin: A. \& A. Farmar.

Klein, Naomi 2000. No logo. Canada: Knopf.

Lash, Scott and John Urry 1987. The End of Organized Capitalism. Cambridge: Polity.

Lebowitz, Michael 2006. Build it Now. New York: Monthly Review.

Lee, Clare 2003. 'Social forums and the global justice movement', unpublished MA thesis, Department of Sociology, National University of Ireland, Maynooth.

Leonard, Liam 2008. The Environmental Movement in Ireland. Dordrecht: Springer.

Macintyre, Stuart 1986. A Proletarian Science. London: Lawrence and Wishart. 2nd edition.

Maeckelbergh, Marianne 2009. The Will of the Many. London: Pluto.

Meade, Rosie 2005. 'Mayday, mayday!', Journalism 9(3): 330-52.

Moffat, Jo 2004. 'Reclaiming the streets', in Michel Peillon and Mary Corcoran (eds), Place and Non-place. Dublin: Institute of Public Administration.

Monbiot, George 2004. The Age of Consent. London: Harper.

Ní Dhorchaigh, Ealair and Laurence Cox 2009. 'When is an assembly riotous, and who decides?' Paper to 'Riotous Assemblies' conference, University of Limerick (November).

Piven, Frances Fox (2008). 'Can power from below change the world?', American Sociological Review 73(1): 1-14.

Polet, François and CETRI 2004. Globalizing Resistance. London: Verso.

Red-Green Study Group (1995). What on Earth is to be Done? Manchester: Red-Green.

Rutkowska, Asia 2010. 'The politics of visual style', paper to 15th 'Alternative Futures and Popular Protest' conference, Manchester.

Sen, Jai 2009. 'Towards walking the earth together', www.openspaceforum.net/twiki/ tiki-read_article.php?articleId $=789$.

Starr, Amory 2000 . Naming the Enemy. New York: Zed.

Stiglitz, Joseph 2007. Making Globalization Work. London: Penguin.

Tormey, Simon 2004. Anti-capitalism. Oxford: Oneworld.

Turbulence 2010. What Would it Mean to Win? Oakland, CA: PM (forthcoming).

Wainwright, Hilary 1994. Arguments for a New Left. Oxford: Blackwell.

Wallerstein, Immanuel 2002. 'New revolts against the system', New Left Review 18 (Nov./Dec.): 29-39.

Waterman, Peter 2001. Globalisation, Social Movements and the New Internationalisms. London: Continuum. 